\title{
Pembangunan Sistem Informasi Alumni Sebagai Pendukung Keputusan Pada Prodi D4 Teknik Informatika Politeknik Harapan Bersama Tegal
}

\author{
Oman Somantri1,*, Dega Surono Wibowo² \\ 1,2 Program Studi Teknik Informatika, Politeknik Harapan Bersama Tegal \\ (corresponding author) oman_mantri@yahoo.com *)
}

\begin{abstract}
Alumni is a resource and when it's not managed properly they cannot be used as an asset to their college. This problem can be solved by making system information to manage the alumni so that management can be done well. One of the efforts to measure the success of this created system is from the evaluation. The acceptance of system information can be measured by several evaluation models that have been developed, namely the Technology Acceptance Model (TAM). TAM is an evaluation model which is often used, with an excess is easy to use. Alumni systems information of D4 Teknik Informatika is a system that can manage data of alumni and activities effectively so that it becomes a most effective decision support
\end{abstract}

\section{Keyword- alumni, Technology Acceptance Model (TAM), information system}

Intisari- Alumni merupakan sumberdaya yang apabila tidak dikelola dengan baik maka para alumni tersebut tidak akan menjadi sebuah sumber daya yang bisa dijadikan sebagai aset bagi perguruan tinggi. Salah satu solusi yang bisa digunakan untuk menangani permasalah tersebut adalah dengan adanya sebuah sistem informasi yang dapat mengelola alumni sehingga pengelolaannya dapat dilakukan dengan baik yaitu dengan dibuatnya sistem informasi alumni. Salah satu upaya yang dilakukan untuk mengukur tingkat keberhasilan sistem yang dibuat adalah dengan melakukan sebuah evalusi sistem. Penerimaan terhadap sistem informasi dapat diukur dengan beberapa model evaluasi yang sudah dikembangkan yaitu Technology Acceptance Model (TAM). TAM merupakan model evaluasi sistem yang sering banyak digunakan, dengan kelebihan salah satunya adalah mudah untuk digunakan. Sistem informasi alumni program studi D4 Teknik Informatika menjadi sebuah sistem yang dapat mengelola data alumni dan aktifitasnya dengan efektif sehingga menjadi sebuah pendukung keputusan yang paling efektif.

Kata Kunci- alumni, Technology Acceptance Model (TAM), sistem informasi.

\section{PENDAHULUAN}

Pada setiap perguruan tinggi peranan alumni sangatlah penting, hal ini dikarenakan alumni mempunyai banyak kontribusi seperti jejaring perusahaan, informasi lowongan pekerjaan, penyandang dana institusi dan lain sebagainya. Alumni merupakan sumberdaya yang apabila tidak dikelola dengan baik maka para alumni tersebut tidak akan menjadi sebuah sumber daya yang bisa dijadikan sebagai aset bagi perguruan tinggi. Dalam hal ini tentunya Prodi D4 Teknik Informatika Politeknik Harapan Bersama harus mempersiapkan dengan matang terkait dengan bagaimana cara untuk mengelola para alumni tersebut sehingga peranan alumni ini bisa diberdayakan dengan baik. Salah satu solusi yang dapat digunakan untuk menangani permasalah tersebut adalah dengan adanya sebuah sistem informasi yang dapat mengelola alumni sehingga pengelolaannya dapat dilakukan dengan baik, yaitu dengan dibuatnya sistem informasi alumni. Sistem informasi adalah suatu kegiatan dari prosedur-prosedur yang diorganisasikan, bilamana dieksekusi akan menyediakan informasi untuk mendukung pengambilan keputusan dan pengendalian di dalam organisasi [1]. Sistem Informasi alumni merupakan sebuah media yang digunakan sebagai pendukung keputusan dalam memutuskan terkait dengan kebijakan yang berkaitan dengan alumni.

Sistem informasi alumni sudah menjadi hal yang sangat penting bagi setiap perguruan tinggi, hal ini menjadikan beberapa peneliti melakukan penelitian untuk membangun sistem informasi ini. Renny, dkk (2013) melakukan penelitian dengan membuat Web Base Career Center dengan berbagai macam pelayanan didalamnya [2]. Sama halnya yang dilakukan oleh Billy, R \& Putra, E (2015) membangun sebuah sistem informasi alumni di Fakultas IImu Komputer Universitas Klabat [3]. Disisi lain penelitian pembuatan sistem informasi alumni dioptimalisasi dengan berbasiskan Sistem Mobile Tracking [4], berbasis layanan [5] [6], serta berbasis Sistem Informasi Geografis [7].

Dalam pengembangan dan pembuatan sebuah sistem informasi alumni, tentunya haruslah sesuai dengan perencanaan dan sesuai dengan rencana serta dapat diterima dan digunakan oleh user, salah satu upaya yang dilakukan untuk mengukur tingkat keberhasilan sistem yang dibuat adalah dengan melakukan sebuah evaluasi sistem. 
Penerimaan terhadap sistem informasi dapat diukur dengan beberapa model evaluasi yang sudah dikembangkan saat ini, diantaranya seperti Technology Acceptance Model (TAM) [8],[9],[10].

Berdasarkan beberapa penelitian yang telah dilakukan, sedikit berbeda dengan penelitian yang telah ada pada penelitian ini sesuai dengan permasalahan yang dihadapi yaitu belum tersedianya sebuah sistem yang terintegrasi untuk dapat mengelola alumni pada program studi D4 Teknik Informatika Politeknik Harapan Bersama Tegal, maka pengembangan dan pembuatan sistem informasi alumni dibangun, dan diharapkan sistem ini dapat dijadikan sebagai pendukung keputusan bagi pihak yang berkepentingan terkait sistem pengelolaan alumni yang akan berjalan.

\section{Metode Penelitian}

\section{A. Data Penelitian}

Dalam penelitian ini bahan penelitian data yang digunakan adalah untuk data pembuatan Sistem Informasi Alumni dan analisis data didapatkan berdasarkan analisis kebutuhan sistem yang berasal dari data-data mahasiswa program studi D4 Teknik Informatika tahun 2016. Data Penelitian yang daidapatkan berupa data mahasiswa serta data kuesioner yang didapatkan pada penilaian hasil umpan balik mahasiswa terhadap institusi yang menginginkan adanya sarana medi komunikasi alumni pada tingkatan prodi.

\section{B. Alat Penelitian}

Penelitian ini dalam proses pengembangan sistem untuk pembuatan sistem Informasi Alumni dalam penelitian ini menggunakan tools software Adobe Dreamweaver dengan bahasa pemrograman PHP.

\section{Metode Pengumpulan Data}

Pengambilan data dilakukan dengan mendapatkan langsung dari objek penelitian yaitu program studi D4 Teknik Informatika berupa data calon alumni serta informasi terkait dengan infrastuktur peralatan yang akan dipergunakan apabila sistem yang telah dibuat di realisasikan. Referensi terkait dengan penelitian yang dilakukan didapatkan dengan melakukan berbagai studi pustaka baik itu di perpustakaan maupun internet untuk mendapatkannya berupa buku dan jurnal-jurnal penelitian.

\section{Metode Pengembangan Software}

Pada penelitian yang dilakukan, pada proses pengembangan pembuatan sistem informasi alumni menggunakan model pengembangan software Object-Oriented Development Life Cycle (OODLC). Pada tahapan ini, beberapa hal dilakukan dengan cara membuat diagram-diagram berbasis UML [11]. Unified Modeling Language (UML) sendiri adalah bahasa spesifikasi standar untuk mendokumentasikan, menspesifikasikan, dan membangun sistem perangkat lunak. yang dipergunakan untuk menggambarkan sistem yang akan dikembangkan, diantaranya adalah:

- Use Case Diagram

- Sequence Diagram

- Collaboration Diagram

- Class Diagram

\section{E. Software Testing}

Pada tahapan ini adalah dilakukannya Software testing, dimana tahapan ini adalah bertujuan untuk mengevaluasi atribut-atribut atau kemampuan sebuah program atau sistem dan penentuan apakah sesuai dengan hasil yang diharapkan. Metode yang digunakan pada proses ini yaitu dengan menggunakan metode Black Box Testing, dimana pengujian ini dilakukan hanya mengamati hasil eksekusi melalui data uji dan memeriksa fungsional dari perangkat lunak dengan kelebihan dapat memilih subset test secara efektif dan efisien, dapat menemukan cacat, dan dapat memaksimalkan testing investment [12].

\section{F. Desain Penelitian}

Pada penelitian ini dilakukan beberapa tahapan dalam pelaksanaannya, sehingga setiap tahapan dilakukan untuk mendapatkan hasil yang lebih baik sesuai dengan tujuan dari penelitian yang dilakukan. Adapun gambaran desain penelitian yang diusulkan adalah seperti tampak pada gambar 1 dibawah ini: 


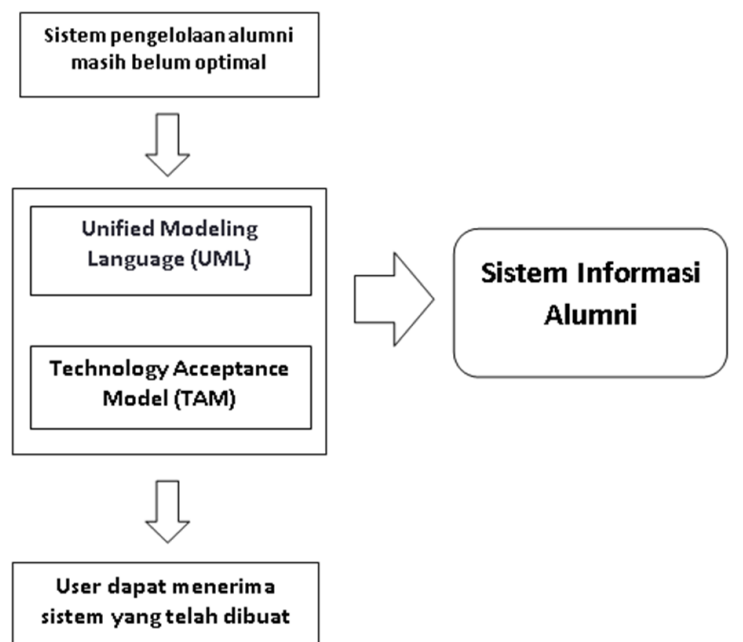

Gambar. 1 Desain Penelitian Yang Diusulkan

Pada penelitian ini, metode yang diusulkan adalah untuk pengembangan system informasi alumni sebuah integrasi antara model pengembangan system perangkat lunak yaitu Object-Oriented Development Life Cycle (OODLC) dengan menggunakan UML serta Technology Acceptance Model (TAM) sebagai model untuk evaluasi system sehingga hasil pengembangan system infomasi yang telah dibuat sesuai dengan apa yang direncanakan dan dapat diterima oleh user [13].

\section{HASIL DAN PEMBAHASAN}

\section{A. Spedifikasi Sistem Yang Digunakan}

Penelitian yang dilakukan menggunakan komputer dengan spesifikasi CPU processor Intel Core i5 2,67Ghz, memory RAM 4 GB serta sistem operasi Windows Professional 7 SP1 32 bit.

\section{B. Desain dan Perancangan Sistem}

Pada proses pengembangan sistem, proses dilakukan dengan menggunakan UML. Pada proses desain pengembangn sistem ini digunakan beberapa diagram sebagai penggambaran dari sistem yang dibuat, diantaranya adalah use case diagram, Activity Diagram, Sequence diagram dan Class diagram.

1) Use Case Diagram:

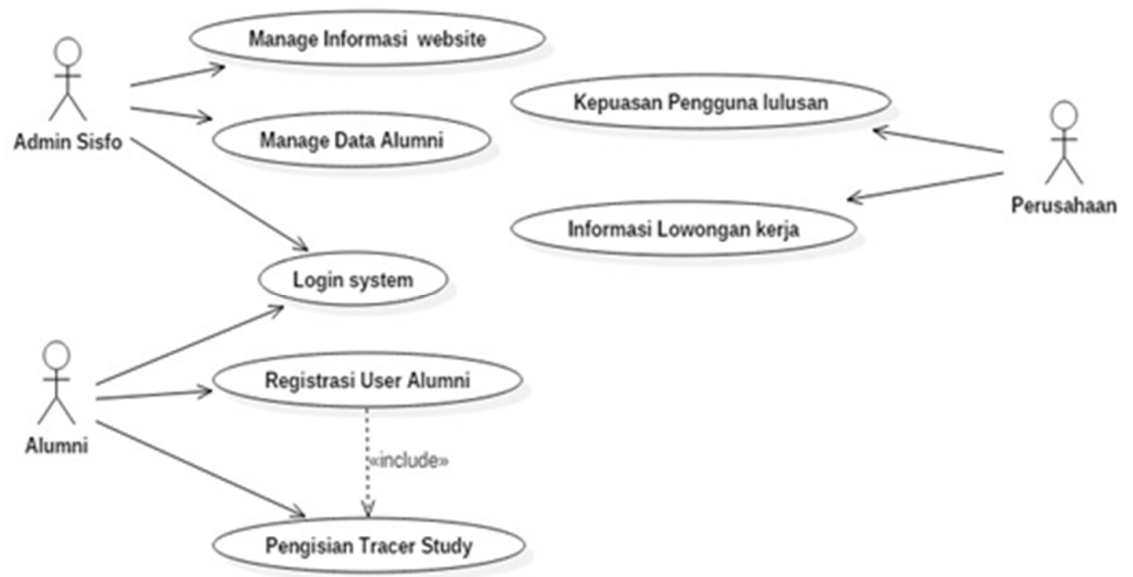

Gambar. 2 Use Diagram sistem yang diusulkan 
Pada gambar 2 diatas menunjukan gambaran use case diagram dari sistem yang dibuat. Aktor yang terlibat dalam sistem adalah alumni, admin sisfo dan perusahaan.

2) Sequence Diagram Alumni

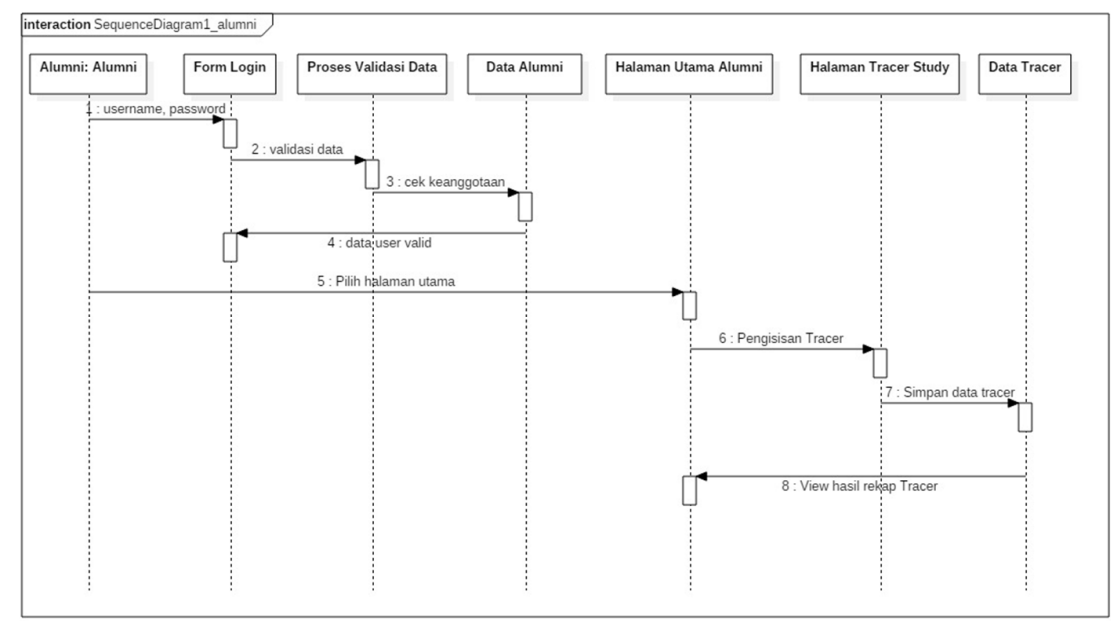

Gambar. 3 Sequence diagram proses fungsional aktor alumni

Pada gambar 3 menunjukan gambaran sebuah diagram sequence sistem informasi alumni yang dilakukan oleh aktor alumni.

3) Sequence Diagram Perusahaan

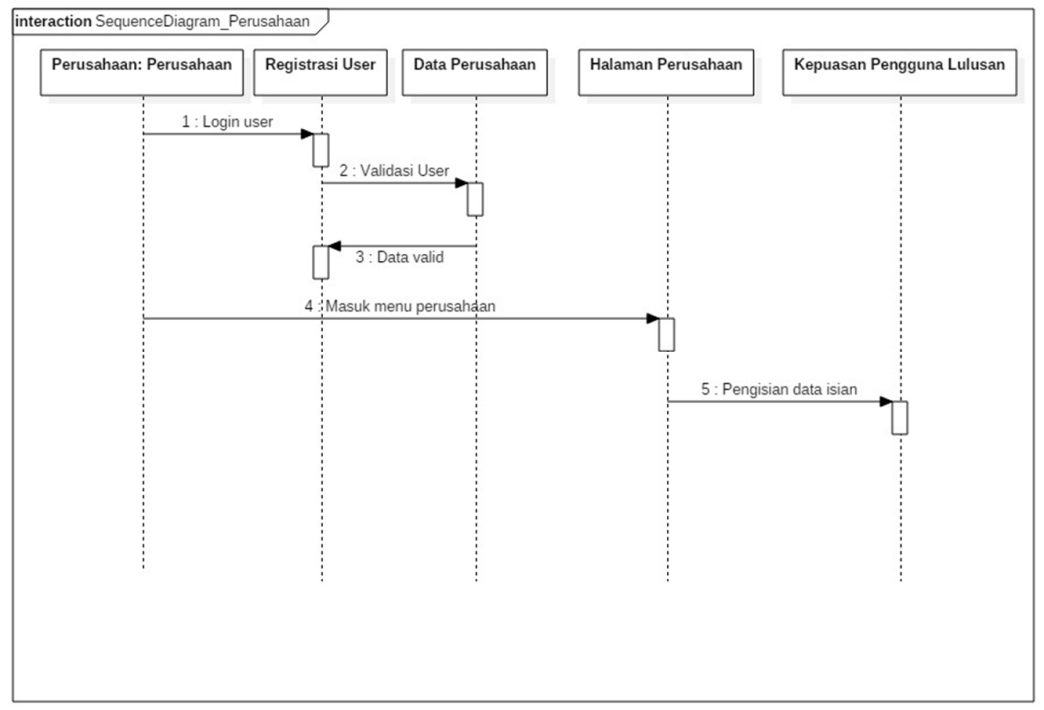

Gambar. 4 Sequence diagram proses fungsional Perusahaan 
Gambar 4 menunjukan bahwa pada aplikasi sistem informasi alumni memberikan sebuh hak akses kepda perusahaan yang menggunakan lulusan alumni untuk dapat memberikan tanggapan terkait dengan lulusan alumni yang dipergunakan.

4) Activity Diagram admin Sisfo

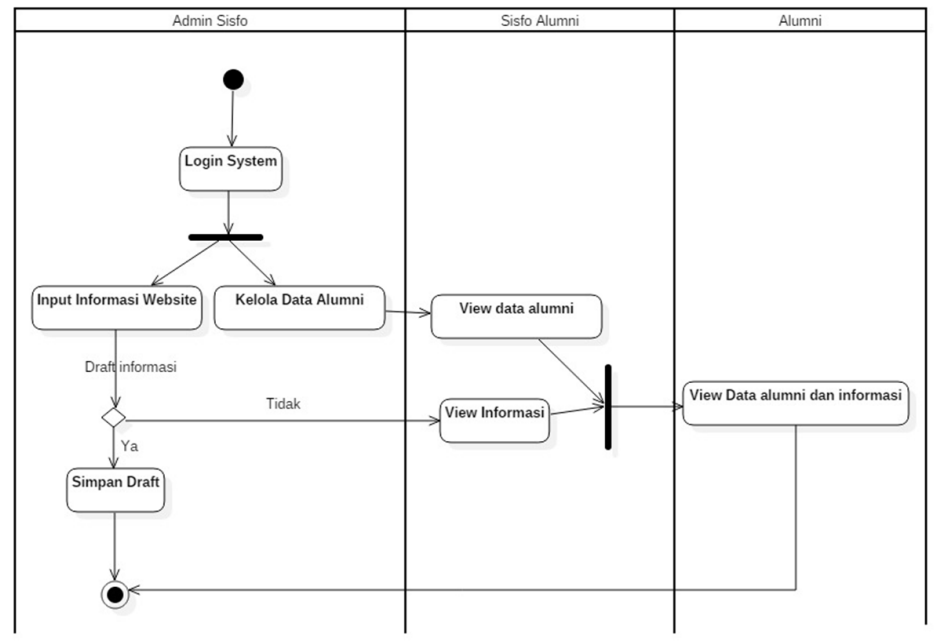

Gambar. 5 Activity diagram bagian admin sisfo

Pada gambar 5 memberikan gambaran aktifitas yang dilakukan oleh admin sisfo. Admin sisfo melakukan segala aktifitas yang dilkukan dengn terlebih dahulu login.

\section{5) Activity Diagram Alumni}

Pada gambar 6 dibawah menunjukan sebuah aktifitas yang dilakukan oleh alumni dalam penggunaan sis informasi alumni. Alumni diberikan hak akses untuk dapat mengisi tracer study terkit dengan kuesioner pelayanan institusi selama alumni masih kuliah.

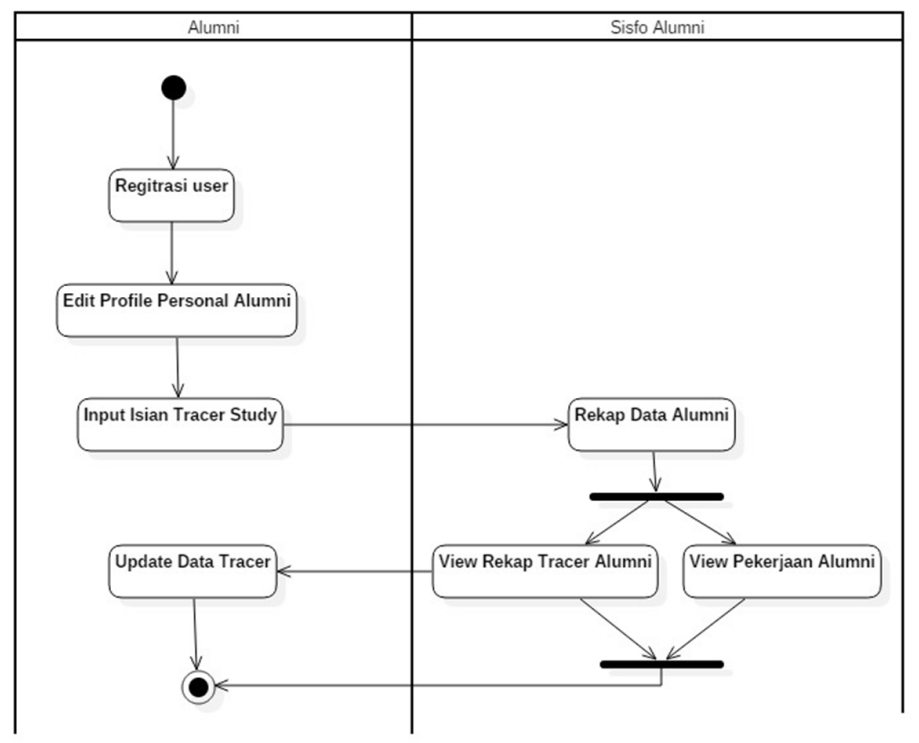

Gambar. 6 Activity diagram bagian Alumni 
6) Class Diagram

Pada penelitian yang dlakukan, untuk desain sistem use case diagram sistem informasi alumni yang dibuat tampak seperti gambar 7 .

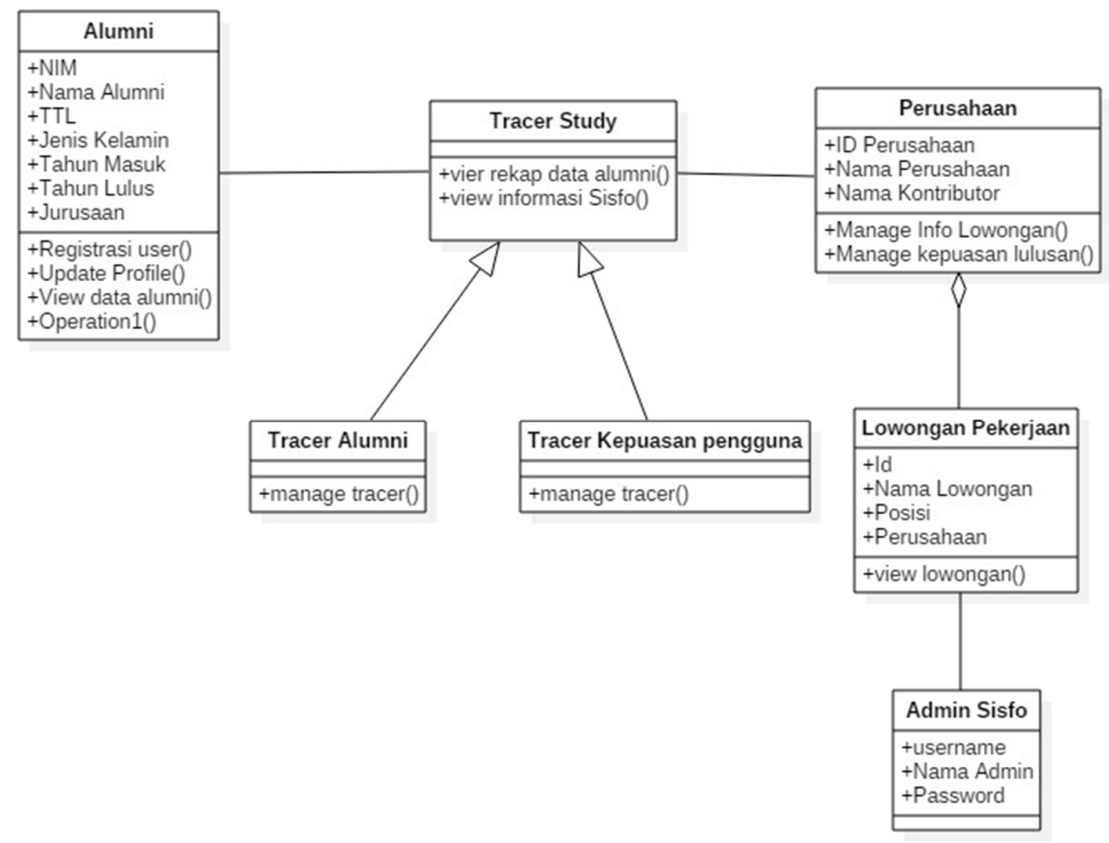

Gambar. 7 Class diagram sistem informasi alumni

Pada gambar 7 memperlihatkan hubungan antar kelas dari sistem informasi alumni yang dibangun. Untuk use case sendiri sesuai pada gambar 7 terdiri dari beberapa class diantaranya class alumni, class tracer study, class perusahaan, class lowongan kerja, class admin sisfo, class tracer alumni dan class tracer kepuasan pengguna.

\section{Implementasi Sistem}

1) Tampilan Halaman Utama

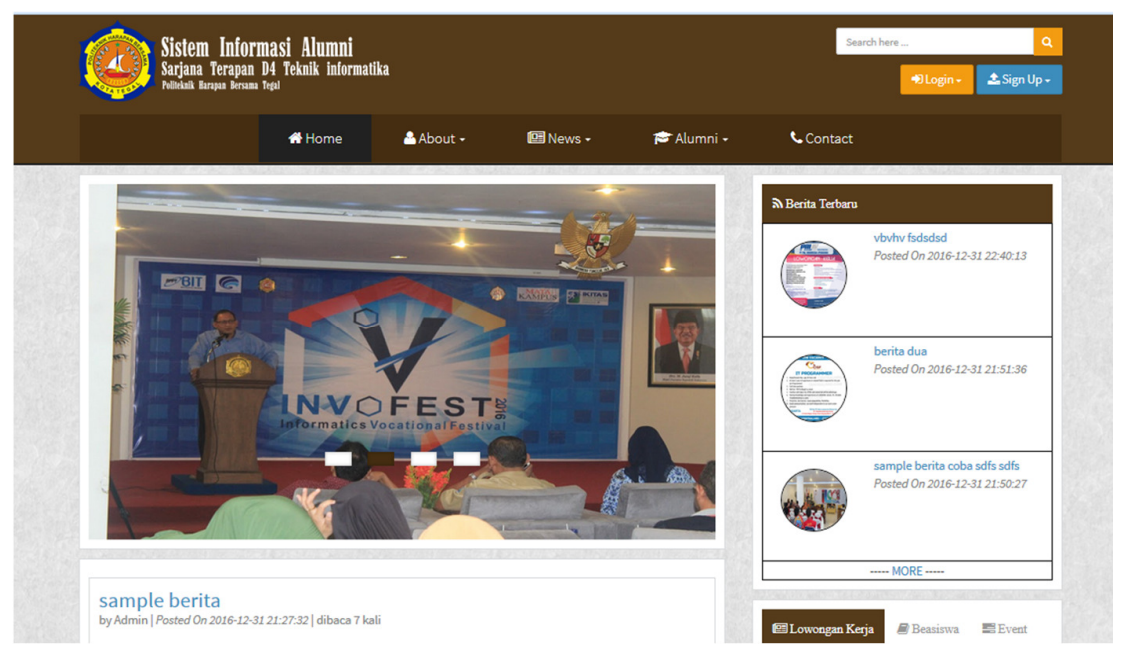

Gambar. 8 Interface halaman utama sisfo alumni 
Gambar 8 menunjukan halaman interface utama sistem informasi alumni. Pda bagian halam utama ini terdiri dari tiga bagian utama yaitu menu home, about, news, alumni dan contact.

2) Halaman Alumni

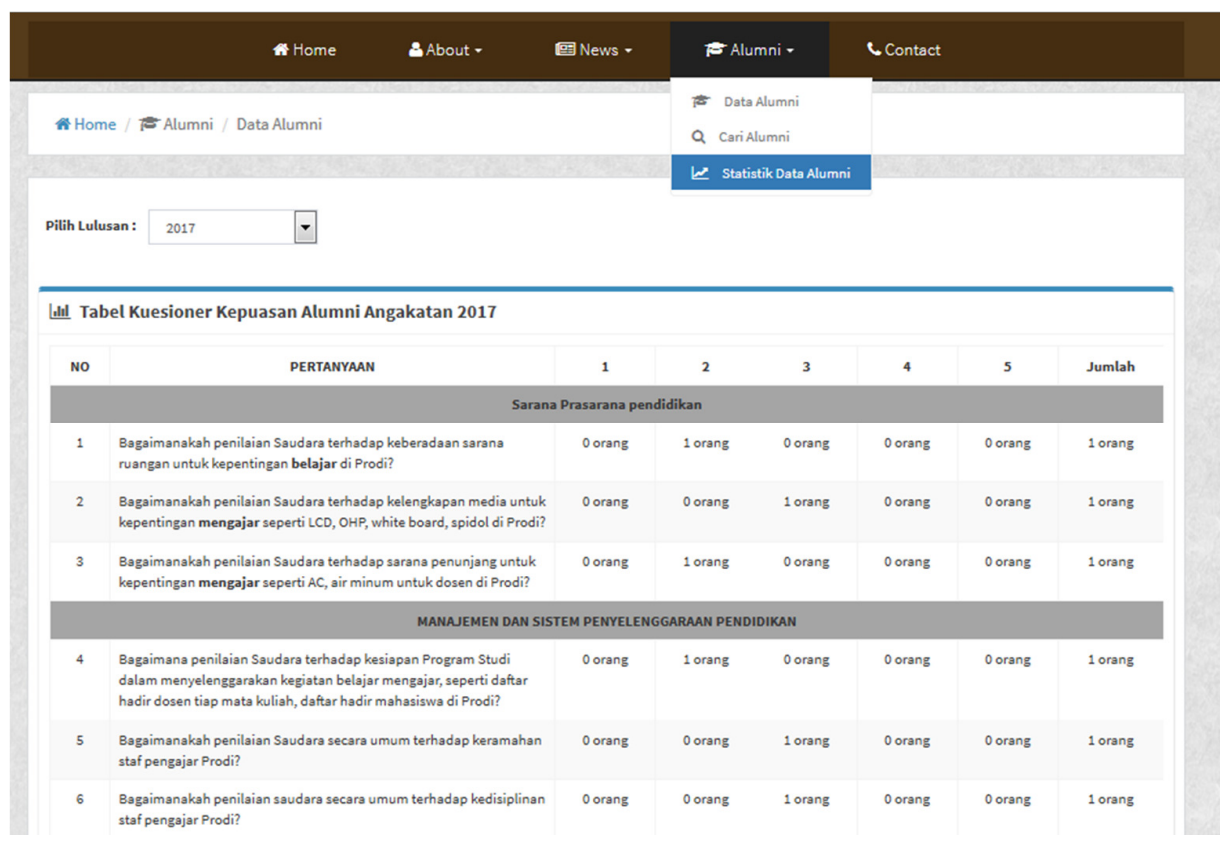

Gambar. 9 Interface halaman alumni

Gambar 9 menunjukan halaman statistik tabel hasil pengisian kuesioner tracer studi yang dilakukan oleh alumni. Halaman merupakan bagian dari halaman user tanpa melakukan login terlebih dahulu dan dapat dilihat oleh semua user yang terdaftar ataupun tidak.

3) Halaman Tracer Study Alumni

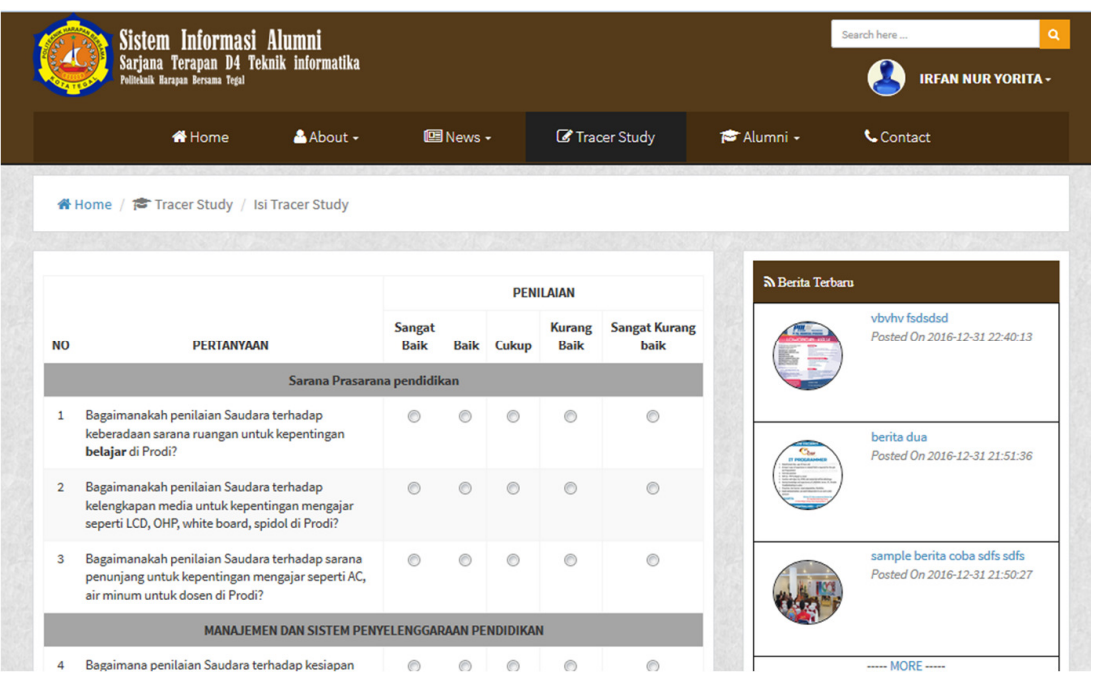

Gambar. 10 Interface halaman alumni untuk tracer study 
Gambar 10 memperlihatkan interface halam alumni untuk pengisian tracer study. Halaman ini akan tampil setelah alumni melakukan login terlebih dahulu pada sistem.

4) Halaman Profile User

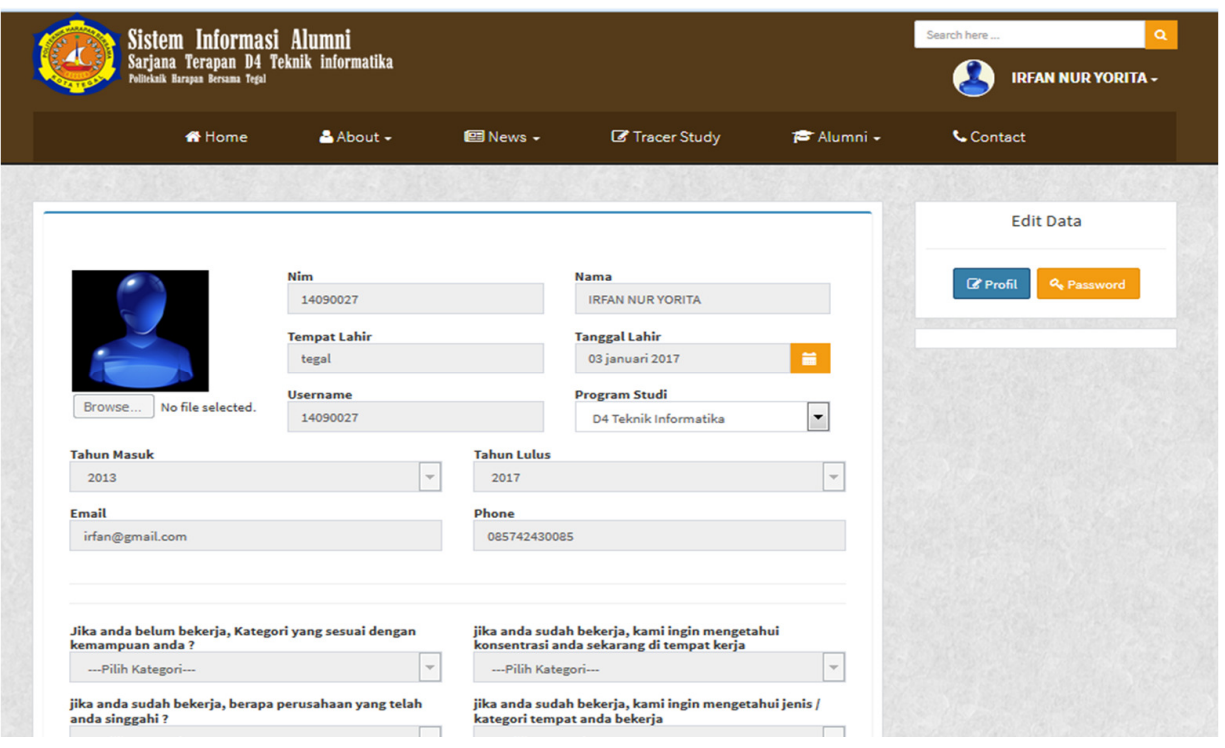

Gambar. 11 Interface halaman profile user

Gambar 11 memperlihatkan tampilan interface halaman user, dimana halaman user tersebut isinya mengenai profile user, serta data kuesioner yang harus diisi oleh user yang dalam hal ini adalah alumni. Hasil kuesioner tersebut nantinya akan masuk kedalam data admin yang akan diguanakan sebagai pendukung keputusan.

5) Interface Halaman Admin

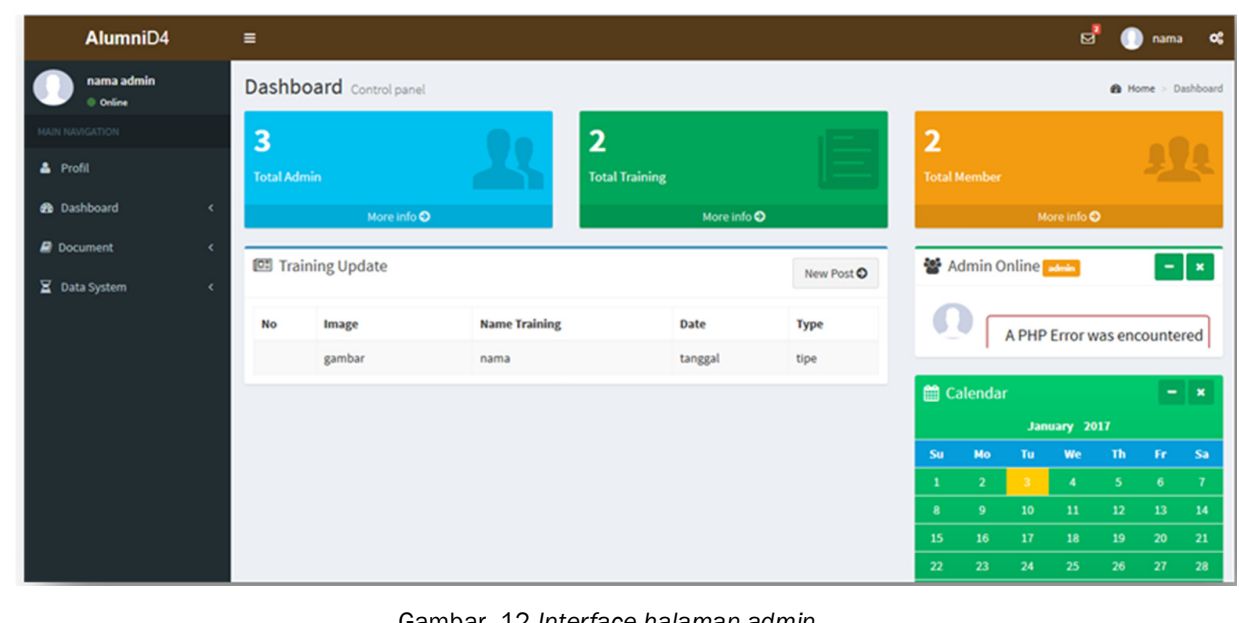

Pada Gambar 12 menunjukan sebuah interface implementasi dari tampilan halaman admin sistem informasi alumni yang dalamnya terdapat menu untuk input dokumen, pengaturan user, dan pengaturan sistem tampilan website. 


\section{Software Testing}

Software Testing dilakukan untuk melihat sejauh mana fungsionalitas sistem informasi yang dibuat apakah sesuai dengan yang telah direncanakan. Testing sistem dilakukan dengan menggunakan test black box. Adapun hasil yang diperoleh adalah seperti pada tabel 1 dibawah ini:

TABEL I

Hasil Test Software Dengan Metode Black BoX

\begin{tabular}{|c|c|c|c|c|c|}
\hline No. & $\begin{array}{l}\text { Komponen } \\
\text { Pengujian }\end{array}$ & $\begin{array}{l}\text { Output yang } \\
\text { Diharapkan }\end{array}$ & Hasil Keluaran & Kesimpulan & $\begin{array}{c}\text { Presentasi } \\
\text { Keberhasilan }\end{array}$ \\
\hline 1 & Halaman Login & $\begin{array}{l}\text { User bisa login dan } \\
\text { masuk ke menu } \\
\text { admin }\end{array}$ & $\begin{array}{l}\text { User bisa masuk } \\
\text { dan login }\end{array}$ & berhasil & $100 \%$ \\
\hline 2 & $\begin{array}{l}\text { Tampilan menu } \\
\text { utama }\end{array}$ & $\begin{array}{l}\text { Menampilkan menu } \\
\text { utama secara } \\
\text { lengkap }\end{array}$ & $\begin{array}{l}\text { Menu utama } \\
\text { website bisa tampil }\end{array}$ & berhasil & $100 \%$ \\
\hline 4 & $\begin{array}{l}\text { Tampilan menu } \\
\text { Tracer Study }\end{array}$ & $\begin{array}{l}\text { Menampilkan } \\
\text { halaman menu } \\
\text { tracer study }\end{array}$ & $\begin{array}{l}\text { Menu dapat } \\
\text { menampilkan } \\
\text { tracer study }\end{array}$ & $\begin{array}{l}\text { Berhasil, hasil analisis } \\
\text { grafik belum maksimal }\end{array}$ & $85 \%$ \\
\hline 6 & $\begin{array}{l}\text { Tampilan menu } \\
\text { Contact }\end{array}$ & $\begin{array}{l}\text { Menampilkan } \\
\text { halaman menu } \\
\text { Contact }\end{array}$ & $\begin{array}{l}\text { Menu Contact } \\
\text { dapat tampil } \\
\text { sempurna }\end{array}$ & berhasil & $100 \%$ \\
\hline 7 & $\begin{array}{l}\text { Tampilan menu } \\
\text { admin }\end{array}$ & $\begin{array}{l}\text { Menampilkan menu } \\
\text { admin }\end{array}$ & $\begin{array}{l}\text { Menu Form admin } \\
\text { dapat digunakan } \\
\text { sesuai fungsinya }\end{array}$ & berhasil & $100 \%$ \\
\hline
\end{tabular}

Pada tabel 1 diatas menunjukan sebuah hasil analisis test software sistem dengan menggunakan metode black box. Dari hasil yang didapatkan terlihat bahwa sistem yang dibuat sudah sesuai dengan perencanaan yang telah direncanakan dan menunjukan 95\% software telah siap untuk digunakan oleh user.

\section{KESIMPULAN}

Setelah dilakukannya penelitian terkait dengan perancangan dan pembangunan sistem informasi alumni dapat disimpulkan adalah Sistem informasi alumni program studi D4 Teknik Informatika menjadi sebuah sistem yang dapat digunakan sebagai alat untuk mengelola data alumni dan aktifitasnya dengan efektif sehingga menjadi sebuah pendukung keputusan yang paling efektif. Evaluasi sistem yang tepat sebagai tolak ukur dari keberhasilan sistem yang dibuat merupakan metode yang tepat untuk mendapatkan sebuah informasi mengenai penerimaan user terhadap sistem sehingga penggunaan sistem tersebut dapat efektif untuk digunakan Pada penelitian selanjutnya perlu dilakukan analisis seperti dengan menggunakan salah satunya adalah metode TAM secara lebih detail.

TAM merupakan model evaluasi sistem yang sering banyak digunakan, dengan kelebihan salah satunya adalah mudah untuk digunakan. Dikarenakan pada analisis penelitian yang dilakukan terbentur dengan masalah waktu penelitian yang dilakukan, maka untuk penelitian selanjutnya adalah perlu adanya pengembangan sistem informasi alumni untuk dikembangkan lebih baik lagi seperti yang dilakukan oleh beberapa peneliti termasuk menganalisis terhdap sistem yang dibuat dengan menggunakan TAM sehingga didapatkan sebuah hasil penelitian kuantitatif yang didapatkan untuk dijadikan sebagai tolak ukur keberhasilan sistem yang telah dibuat. 


\section{REFERENSI}

[1] Jogiyanto, H. M. "Metodologi Penelitian Sistem Informasi." Yogyakarta: Penerbit Andi (2008).

[2] Renny, Chandra. "R., Ruhama, S. \& Sarjono, MW, 2013." Exploring Indonesian Web Based Career Center Discrepancy of Web Popularity and Type of Services, UACEE International Journal of Advances in Computer Science and its Applications-IJCSIA 3, no. 2: 212-16.

[3] Billy, R. E., \& Putra, E. Y. (2015). Sistem Informasi Alumni Fakultas IImu Komputer Universitas Klabat. Proceedings Konferensi Nasional Sistem dan Informatika (KNS\&I).

[4] Sumardi, Sumardi. "Rancang Bangun Sistem Mobile Tracking Untuk Penelusuran Alumni Dengan Menggunakan Media Google Map Api Dan Sms Tracing." INFOKAM 12, no. 2 (2016).

[5] Ananda, Dahliar. "Pemodelan Sistem Informasi Layanan Karir Dan Alumni Politeknik XYZ." SEMNASTEKNOMEDIA ONLINE 4, no. 1 (2016): 4-11.

[6] Romadhoni, E. N. A., Widiyaningtyas, T., \& Pujianto, U. (2015). Implementasi Model Waterfall Pada Pengembangan Sistem Informasi Alumni SMKN 1 Jenangan Ponorogo. SESINDO 2015.

[7] Wibowo, Firman Teguh, Ika Purwanti Ningrum, and Bambang Pramono. "Sistem Informasi Alumni Berbasis Gis (Studi Kasus: Fakultas Teknik Universitas Halu Oleo)." semanTIK 2, no. 2 (2016).

[8] Dulcic, Z., Pavlic, D., \& Silic, I. (2012). Evaluating the intended use of decision support system (DSS) by applying technology acceptance model (TAM) in business organizations in Croatia. Procedia-Social and Behavioral Sciences, 58, 1565-1575.

[9] Kim, Y. G., \& Woo, E. (2016). Consumer acceptance of a quick response (QR) code for the food traceability system: Application of an extended technology acceptance model (TAM). Food Research International, 85, 266-272.

[10] Pai, F. Y., \& Huang, K. I. (2011). Applying the technology acceptance model to the introduction of healthcare information systems. Technological Forecasting and Social Change, 78(4), 650-660.

[11] Larman, Craig, and U. M. L. Applying. "Patterns: An Introduction to Object-Oriented Analysis and Design and Iterative Development." (2004).

[12] Beizer, Boris. Black-box testing: techniques for functional testing of software and systems. John Wiley \& Sons, Inc., 1995.

[13] Venkatesh, Viswanath, and Fred D. Davis. "A theoretical extension of the technology acceptance model: Four longitudinal field studies." Management science 46.2 (2000): 186-204. 